\title{
Mysticism, Pietism, Morality: An Introduction
}

\author{
Patrick Benjamin Koch
}

The aspiration to seek proximity to the divine, as well as the attempts to translate such aspirations into action, is at the core of many writings that scholars have labeled as 'mystical.' Equally, this desire determines the self-imposed lifestyle of individuals who are commonly referred to as 'pietistic.' Both outlooks have far-reaching implications that revolve around the question of how the mystic, or the pietist, ought to act towards God and within society. These aspects can be subordinated to the generic term 'praxis,' and they are frequently negotiated under the rubric of 'morality.'

In Jewish literature, topics of this kind are frequently associated with the notion of musar. There is no clear and simple answer to the question of what musar means. This is not only due to the fact that the use of the term looks back to a long history - from the Bible to the present day - and that it has thus been employed with many different connotations and in different contexts; it is also mainly because there is no consensus on what is understood as morally correct and what is understood as morally reprehensible. Musar manifests itself in multiple genres, multiple stylistic garbs, and multiple languages. It can offer general principles for spiritual improvement or clear instructions for everyday conduct, provide strategies for change by deliberately triggering feelings of anxiety, and serve, in the biblical sense of the word, the function of an admonisher. Understanding musar as a literary mode rather than a specific genre opens new perspectives on aspects that have received little attention in research to date. This includes the psychological dimension of musar - a topic that plays a central role in several of the contributions published in the present issue.

'Mysticism,' 'pietism,' and 'morality' are highly fascinating, yet somewhat artificial analytical categories when it comes to the study of Judaism. In fact, all

1 Here, I am following the rabbinic understanding of the Hebrew term hasid as someone who goes beyond the letter of the law and of 'saintliness' [hasidut] as "a divine and lofty type of piety, and a higher morality, not bound by law" (see e.g., Joseph Jacobs and Judah David Eisenstein, "Saint and Saintliness," Jewish Encyclopedia, ed. Isidore Singer [New York: Funk \& Wagnalls, 19o6], vol. 10, 637). 
three have been repeatedly contested. Some scholars have argued that the idiosyncratic features of the different types of mystical thought and experience are misconstrued when they are understood as "universal trans-historical, inherent [...] phenomena," as they factually represent a "modern, culturally-dependent, discursive construction."2 Others seem rather worried about the use of etic terms in general and about the possible concealment of the 'Jewishness' of the material in particular. Accordingly, it has been suggested, for example, that we do not use the term 'mysticism' nominally, but rather attributively, in order to stress that these materials offer a genuine Jewish reading of a quintessentially Jewish world of ideas. ${ }^{3}$ However, if one defines mysticism most broadly as "a current within religions and cultures associated with voluntary efforts aimed at gaining an intensified experience of the sacred," ${ }^{4}$ pietism as a type of introspection with an "emphasis on the experimental over the intellectual" that calls for "sustained moral training" and provides a "program for the vigilant disciple of the soul," ${ }^{5}$ and morality as a "reflection on issues pertaining to moral rules and guidelines (i.e., 'what should one do?') as well as a means of clarifying issues related to the development of moral character and virtues in a human being (i.e., 'what should one become?'),"6 then one can certainly detect phenomena in Jewish literature that correspond to these characteristics.

2 See Boaz Huss, "Jewish Mysticism: The Invention of an Unbroken Jewish Tradition," http:// www.cismor.jp/uploads-images/sites/2/2018/05/Jewish-Mysticism-The-Invention-of -an-Unbroken-Jewish-Tradition.pdf, accessed 16 June 2020, 19-20. For a more comprehensive discussion, see also idem, The Question about the Existence of Jewish Mysticism: The Genealogy of Jewish Mysticism and the Theologies of Kabbalah Research (Jerusalem and Tel Aviv: Van Leer Institute Press and Hakibbutz Hameuchad Publishing House, 2016) [Hebrew].

3 The most outspoken representative of this position is Yehuda Liebes. See e.g., the interview published in Musaf Maqor Rishon-Shabbat on 17 February 2017, https://musaf-shabbat. com/2017/o2/19/לאהוב-מבלי-להיבלע-אריאל-הורוביץ/, accessed 16 June 2020. For a refusal to use the term 'Jewish ethics,' see Yeshayahu Leibowitz, Sihot al Messilat Yesharim le-Ramhal (Jerusalem: Hemed, 1997), 25.

4 Sara Sviri, "Sufism: Reconsidering Terms, Definitions and Processes in the Formative Period of Islamic Mysticism," in Les maîtres soufis et leurs disciples des IIIe-Ve siècles de l'hégire (IXe-XIe): Enseignement, formation et transmission, eds. G. Gobillot and J.-J. Thibon (Beyrouth: Institut Français du Proche-Orient, 2012), 17-34, here 20.

5 Haym Soloveitchik, "Piety, Pietism and German Pietism: Sefer Hasidim I and the Influence of Hasidei Ashkenaz," Jewish Quarterly Review 92(3-4) (2002):455-493, here 473; see also Gershom Scholem, "Three Types of Jewish Piety," Ariel: A Quarterly Review of Arts and Letters in Israel 32 (1973): $5^{-24}$. It is noteworthy that as early as 1926, the historian Simon Dubnow understood the epithet hasid in its medieval Ashkenazi sense as 'pietist' or 'mystically tempered spirit' (see idem, Weltgeschichte des jüdischen Volkes [Berlin: Jüdischer Verlag, 1926], vol. 4, 333-339).

6 G. William Barnard, "Introduction," in Crossing Boundaries: Essays on the Ethical Status of Mysticism, eds. G. William Barnard and J. J. Kripal (New York: Seven Bridges Press, 2002), 1-11, here 3 . 
Jewish mystical, pietistic, and moralistic notions are deeply rooted in rabbinic discourses. It is well known, however, that medieval, early modern, and modern authors transposed the rabbis' oftentimes ambivalent attitudes into their own socio-historical realities, combining them with new emerging intellectual trends and bodies of knowledge. Thus, for example, many kabbalists often envision the divine realm as simultaneously monistic and dualistic. This conception of the cosmos quite obviously has consequences for human conduct in general. In concrete terms, this means that a Neoplatonically-inspired monism would usually translate into a rather negative bodily regimen or into a deep mistrust in all worldly affairs, since they could prevent the soul's re-connection with its origin. Such a mentality proposes an ascetic lifestyle that includes the subjugation of the self and physical seclusion from the community-aspects that may be interpreted as asocial, and at times even as antisocial. The kabbalists' dualism, on the other hand, is characterized by a strong anthropocentrism that focuses on the impact of human activity on the Godhead-a notion that can potentially valorize any physical action when accompanied by their proper mystical intentions as an essential aspect of a mystico-pietistic path. In this context, commandments that concern the interpersonal also serve a theurgical purpose. Very often, these two fundamentally different approaches are so closely fused together that they open up entirely new possibilities for interpreting the relationship between God, humans, and the world. For the kabbalists, this means that the soul's attachment to, or unification with, the divine is an important objective. However, tearing the balance of the binaries of good and evil, mercy and judgment, or the masculine and feminine forces in the upper worlds by means of theurgical, corporeal actions - and on a daily basis - is considered no less important. Of course, such integrative attempts are not only found in kabbalistic texts. Gershom Scholem, for example, had already pointed out that in medieval Ashkenazi Hasidism, the two main figures of the movement, Judah he-Hasid (1150-1217) and his father Shmu'el, are portrayed in Sefer Hasidim as saints who "harmoniously combine" the aspects of "radical, anti-social, introspective devotion to the ideal, and loving care for the maintenance of the community"7 - a trait that can be found surprisingly often when comparing the recommended lifestyles propagated in musar literature with the social commitments of its authors. ${ }^{8}$

7 Gershom Scholem, Major Trends in Jewish Mysticism (New York: Schocken Books, 1995), 173.

8 From the little biographical data we possess, one can still deduce a tendency that many of the authors of texts that propagate an ascetic lifestyle simultaneously held leading positions within their community and performed tasks that went hand-in-hand with social responsibilities. 
Some of the compelling questions that emerge against the background of these sketchy remarks are: In what ways do the relationships between mysticism, pietism, and morality manifest themselves in Jewish literature? What tensions arise due to the partly contradictory ideals conveyed in different perceptions of the cosmos? And in what way are such apparent contradictions reconciled? The present special issue brings together several studies that address these as well as many other questions that shed light on how notions of the mystical, the pietistic, and the moralistic are negotiated in different historical, geographical, and ideological contexts.

In "Gazing into Their Hearts: On the Appearance of Kabbalistic Pietism in Thirteenth-Century Castile," Jeremy Brown offers a thorough analysis of Moses de León's (c. 1250-1305) "Order of Penitents," a thirteen-step program for pietistic living that is part of a larger unpublished "unnamed composition" by the same author. Brown convincingly argues that a penitential ethics based on kabbalistic concepts had already developed in thirteenth-century Castile and suggests regarding the "unnamed composition" as a source of the theosophicalmoral teachings articulated in the Zohar. His assessment is therefore not only significant for today's highly specialized Zohar research; it also contributes to our understanding of de León's use of the term teshuvah, one that he supposedly developed in either dialogue or competition with contemporaneous Franciscan notions of penitence and the mendicant orders that were flourishing in Western Europe. In doing so, Brown shows how, according to de León, the divine structure represents the model for supererogatory human conduct. By applying this supererogatory ethics, the penitent causes divine mercy to permeate all levels of being.

Expanding on his earlier studies on hypernomianism, in "Heeding the Law beyond the Law: Transgendering Alterity and the Hypernomian Perimeter of the Ethical," Elliot Wolfson elaborates in great detail on the ethical implications that result from the concept of a concealed messianic Torah-a Torah that, according to some kabbalistic and Hasidic masters, exists alongside the revealed nomian one, and that constitutes a different set of laws that exceed the boundaries of the former. He argues that the perception of the infinity of the One as either an identity of difference or a difference of identities challenges the conventional nomian and moralistic structure insofar as it transcends the possibility of thinking in opposites. In this light, and in contrast to the Scholemian idea of the antinomian, the messianic Torah is hypernomian: it constitutes a law beyond law. Particularly revealing is Wolfson's discussion of how the kabbalists perceive the nomian Torah as originating from the Tree of Knowledge and as being clothed in the shell of the demonic. This thought-provoking concept 
raises the broader questions of the relationship between the demonic and the nomian and the temporary validity of the nomian, as well as its interaction with the hypernomian.

In "Repentance through Fear: Cosmic and Body Horror in Shevet Musar," Ilaria Briata takes the highly influential moralistic treatise Shevet Musar by Elijah ha-Kohen Itamari (died 1729) as an opportunity to ask whether it is possible to speak of Jewish horror as an analytical category. Reading Shevet Musar as a textual 'emotion machine,' a concept coined by Ed Tan, ${ }^{9}$ Briata shows how Itamari uses horror-understood as a psychological experience rather than a specific genre-as a moralizing tool. Her discussion of the textual examples and their detailed visualizations of the terrifying images illustrates very vividly how emotional anticipation functions as a rhetorical key to moral direction. Briata's case study of Shevet Musar raises further questions about the importance of intimidation and fear in moralistic literature in general and the psychological effects they have beyond the immediate reading experience in particular. With reference to the terminological limitations of the designations of 'ethics' and 'morality', Briata suggests considering 'psychology' in the sense of "discourse on or for the soul" as an appropriate term for a literature aiming at spiritual refinement.

Jonathan Garb's essay "From Fear to Awe in Luzzatto's Mesillat Yesharim" investigates the various connotations of yir'ah, a term that designates one of the key concepts of musar. Garb argues that Moshe Hayyim Luzzatto (17071746) moves away from deploying yir'ah to signify the 'fear' of punishment to instead describe an emotional state of 'awe' of the divine presence. He further shows that Luzzatto himself sets a most intriguing example, as he personifies the ostensibly contradictory positions of messianic aspiration and mystical vision and the staunch support of nomian values. The dynamics between these two poles and the ways they are reflected in Mesillat Yesharim are at the core of Garb's discussion. He characterizes this dual approach as both psychological and halakhic - one that does not distinguish between practical and internal matters. Against this background, Garb proposes understanding musar by extension as an engaged reflection amidst the travails of daily life.

Focusing on the role of religion and its ethical norms in maskilic literature, Elke Morlok's “Isaac Satanow (1732-1804) on Moral and Intellectual Perfection" investigates the significance of musar in the formation of Jewish modernity.

9 Ed S. Tan, Emotion and the Structure of Narrative Film: Film as Emotion Machine (Hillsdale, NJ: Lawrence Erlbaum, 1996). 
Her thorough analysis of Satanow's writings, in particular the 'twin sisters' of Imrei Binah and Sefer ha-Middot, illustrates how they deal with questions of intellectual and moral perfection respectively and how the maskilic idea of complementary theological and philosophical morals materializes in Satanow's writings. By outlining Satanow's attempt at harmonizing the mystical, the (theologico- and philosophico-) ethical, and the scientific, Morlok emphasizes the educational value of this method, as it exposes his traditional readership to a secular rationalism on the one hand and those who were familiar with contemporary scientific and philosophical discourses to esoteric religious ideas on the other.

In "Abraham Unbound: The Prefiguration of the Unconscious in the First Generation of the Musar and Hasidic Movements," Clémence Boulouque offers an insightful discussion of how differently the notion of the unconscious was negotiated in the early writings of arguably the two most influential Jewish spiritual movements of the nineteenth century. Juxtaposing the founding figure of the Musar movement's interest in ethics and psychology with what Gershom Scholem has described as the 'mystical psychology' of Hasidism, Boulouque shows how Israel Salanter's (1810-1883) notion of the unconscious transposes the secular into religious terms and therefore reflects an attempt to harmonize scientific discourses with traditional Jewish thought. For Salanter, Boulouque argues, the unconscious is a way of decrypting one's dark powers and of examining and consolidating one's faith. In contrast, the Maggid of Mezeritch (died 1772), one of the most formative figures of the nascent Hasidic movement, perceived the unconscious as a link with the primordial intellect, which can be reached via meditation.

The present collection of articles does not suggest a specific hierarchy between mysticism, pietism, and morality, nor does it necessarily address all of them equally. It does, however, show that pietism does not always serve an instrumental purpose of attaining ecstatic states, but that it can also be envisioned as an essential part of an everyday mystical lifestyle, that kabbalistic writings can convey a deep sense of moral responsibility, which need not necessarily also be ethical, and that morality does not always have to be negotiated interpersonally, but rather often takes the form of an intensive dialogue with the self. In view of these considerations, as well as the sheer quantity of primary sources that would be worth further investigation, it is self-evident that the present issue makes no claim of completeness. Rather, it intends to offer several case studies that illustrate the benefits of taking pietistic and moral dimensions into consideration when investigating the mystical and vice versa. 


\section{Acknowledgments}

The six essays presented in this special issue are the results of two international workshops that were organized by the Emmy Noether Group "Jewish Moralistic Writings (Musar) of the Early Modern Period: 160o-180o" (Project No. 320105005) funded by the German Research Foundation (DFG). The first event, "Varieties of Musar: Sociological, Historical, and Literary Perspectives," was held at the University of Hamburg on 28-29 August 2018. It focused on the diverse manifestations of musar literature and explored some of the difficulties surrounding the definition, function, and reception of this textual corpus. The second event, "Piety, Politics, and the Self: Trends in Early Modern Musar," was a collaborative effort held at the Institute for Israel and Jewish Studies at Columbia University in New York City on 15 May 2019. Both events were facilitated by the generous support of the German Research Foundation.

First of all, I would like to express my biggest thanks to the authors, who not only agreed to contribute to this project, but also presented highly original studies that in my opinion will have a lasting impact on future scholarly debates on the entanglements of the mystical, the pietistic, and the moral in general and on musar in particular. I would also like to thank them for their pleasant, amicable, and respectful cooperation. I am particularly grateful to the director of the Institute for Israel and Jewish Studies at Columbia University, Elisheva Carlebach, for her enthusiastic cooperation with our research group and to the Institute's assistant director Dana Kressel for the superb organization and implementation of our gathering in New York. On the Hamburg side, I would like to thank my colleagues Karolin Berends, Ilaria Briata, Giada Coppola, Sophia Hernandez Santana, Libera Pisano, Benjamin Rogler, Amalia Stulin, Maria Wazinski, and Daniel Weissmann. I would also like to express my heartfelt thanks to Avriel Bar-Levav, Jeremy Dauber, Matthias Lehmann, Elly Moseson, David Sclar, Katja Smid, and Vered Tohar for their participation in the above-mentioned workshops and their important contributions to the general discussion that helped to shape the present issue in many ways. I am especially pleased to have had the opportunity to publish this collection of essays with the European Journal of Jewish Studies. In this respect, I would like to express my gratitude to the journal's Editor-in-Chief, Giuseppe Veltri, to whom I am also deeply indebted for the support and trust that he has shown me over the past years, to Katelyn Chin and Brenda Kaldenbach from Brill, and to Dirk Bakker, Katharine Handel, and Elisa Thiele for their outstanding support in the copyediting process. Last but not least, I am incredibly grateful to be part 
of the Emmy Noether Program, which over the last three years has given me the opportunity to discuss my research on the mystical, pietistic, and moral dimensions of Jewish literature with 'kindred spirits,' and to share the outcome of these encounters with a broader audience in publications such as this.

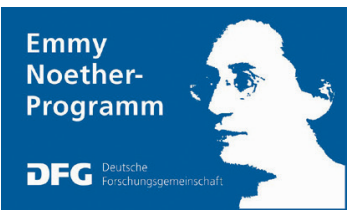

